INTERNATIONAL DESIGN CONFERENCE - DESIGN 2018

https://doi.org/10.21278/idc.2018.0539

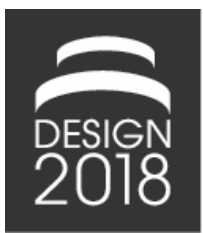

\title{
RESILIENT DESIGN PROPERTIES OF A DRIVERLESS TRANSPORT SYSTEM
}

\author{
M. Wied, J. Oehmen and T. Welo
}

\begin{abstract}
From its origin in ecology, resilient system properties have attracted wider interest for their applications to man-made systems. Previous research has shown that a simple conceptual model seems to capture much resilience thinking across disciplines and system types. In this paper, we apply that model to study resilient properties in the design and development of an autonomous public transport system, attempting to circumvent the problem of commitment under uncertainty. We identify a number of resilient system properties and classify them by function into six distinct categories.
\end{abstract}

Keywords: complex systems, risk management, project management, design strategy

\section{Introduction}

Many important events in a system's life cycle cannot be known in advance. Nonetheless, irreversible up-front design commitments have to be made. Addressing the problem of commitment under uncertainty, this paper argues that systems should generally be designed to perform under a wider range of conditions, than traditionally considered. In other words, systems should be more resilient to changing conditions. This problem is part of the wider challenge of implementing design strategy under uncertainty.

Originally conceptualised for understanding natural systems, resilient system properties have recently gained wider interest for their application to the design of man-made systems. A literature review (Wied et al., under review) has shown that much resilience thinking, currently fragmented across disciplines and system types, is captured by a relatively simple conceptual model. This paper applies those concepts to study resilient properties in the design and development of a real-world system, asking: How do resilient properties modify the relationship between performance and condition variables in the design and development phase of a driverless transport system?

In doing to, we aim to better understand what resilient properties are, and how they can be practically applied to the design of man-made systems.

The remainder of this paper is organised as follows: Section 2 outlines the fundamental design problem of commitment under uncertainty. Section 3 introduces and defines resilient system properties, while Section 4 applies these concepts to identify resilient system properties in a case study of a real-world system under design. Finally, Section 5 proposes a classification of resilient properties in systems design.

\section{A fundamental design problem}

According to Simon (1997, p. 111), "Everyone designs who devises courses of action aimed at changing existing situations into preferred ones". However, many important events in a system's life cycle cannot be known in advance. Nonetheless, design commitments have to be made. Following Hubbard (2009, 
p. 80) uncertainty is defined as "the lack of complete certainty - that is, the existence of more than one possibility. The "true" outcome/state/result/value is not known".

The problem of commitment under uncertainty has been studied extensively in many fields, including game theory (von Neumann and Morgenstern, 1944), problem solving (Rittel and Webber, 1973), strategy (Schelling, 1980), policy planning (Lempert et al., 2003), and elsewhere. The problem arises when both uncertainty and commitment are present. Uncertainty without commitment holds open the option of correction when uncertainties are resolved. Conversely, commitment without uncertainty enables designing for certain conditions, without the possibility of error.

The combination of uncertainty and commitment is widely recognised in the literature on systems design. Veenvliet et al. (2011) consider the problem of commitment under uncertainty inherent to the design of all engineering systems: Early commitments are made under uncertainty, which subsequently decreases throughout the system's life cycle. In parallel, commitment increases as irreversible decisions compound. This fundamental problem is illustrated in Figure 1.

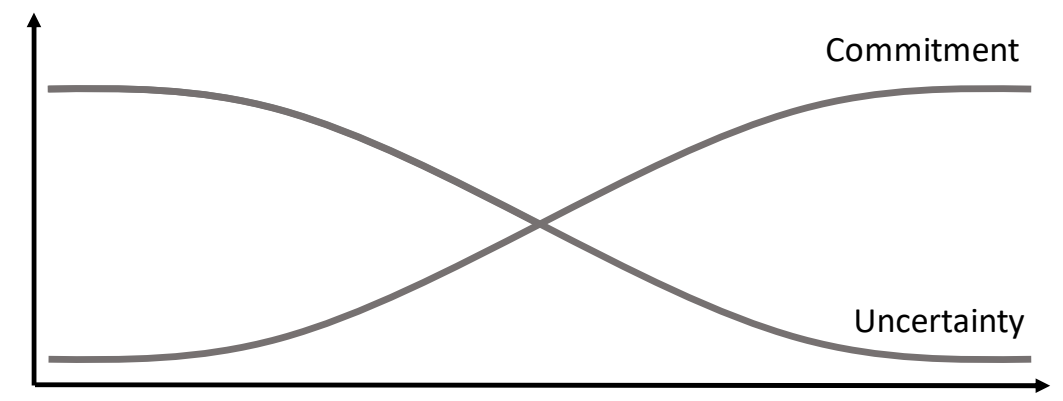

Figure 1. Commitment and uncertainty through a system's life cycle

The basic plot of the upward-sloping commitment curve and the downward-sloping uncertainty curve is featured in many design, engineering, and management models. The uncertainty curve is reflected in the 'cone of uncertainty', describing decreasing uncertainty over the system's life cycle as sources of variability are eliminated (Antunes and Gonzalez, 2015). Early work by (Merrow et al., 1981, p. 32) draw a similar cone when studying the increasing accuracy of cost estimates through the progression of the design process. Earlier still, Arrow $(1955$, p. 3$)$ observed that in military R\&D projects " $[\ldots]$ the a priori probability distribution of the state of nature [...] is relatively flat to begin with. On the other hand the successive posteriori distributions after more and more studies have been conducted are more and more sharply peaked or concentrated in a more limited range, and therefore we have better and better information for deciding what the next step shall be". More recently, declining uncertainty curves are used as a measure of risk reduction in 'risk burn-down charts' (Chaudhuri and Chaudhuri, 2011).

Turning to the upward-sloping commitment curve, this phenomenon is also treated widely in the literature. It is captured by the 'cost of change' curve, i.e. the cost of undoing earlier decisions (Mitchell, 1985). Other authors draw a similar curve by plotting cumulative expenditure against time (Maylor, 2010 , p. 34). Aaltonen et al. (2017) investigated 'path dependence' in decisions, showing how early decisions constrained the scope of later ones. The phenomenon of commitment is likewise captured in the 'constraints of physicality' emphasised by iterative design paradigms (Sebastian, 2017). Here, a distinction is made between material and non-material systems. It is argued that the former is subject to the laws of physical matter, and are less malleable than non-material systems e.g. information, organisational, or service systems, etc. In the following, resilient system properties are introduced as a possible solution to the design problem of commitment under uncertainty.

\section{Resilient system properties}

Etymologically meaning to 'rebound' (Rose, 2017), the concept of resilience was first introduced by Holling (1973) in the field of ecology, and has now been applied in many other fields (Hosseini et al., 2016). In engineering, the application of resilient properties is relatively new compared to other domains (Hosseini et al., 2016), and was introduced by the safety engineering community (Woods, 2006). 
However, as noted by (Martin-Breen and Anderies, 2011, p. 13), "there remains a considerable amount of work before resilience in systems will be a useful off-the-shelf concept for practitioners".

To this end, based on the work of Carpenter et al. (2001) in the field of ecology, Wied et al. (under review) proposed a simple conceptual model for understanding resilience in engineering systems. This model seems to underpin much resilience thinking across disciplines and system types in the literature. The model distinguishes between performance variables, condition variables, and resilient properties in any system. Performance variables are the set of value variables defining the performance of a system. These are output variables, whose attributes are to be preserved, minimised, or maximised. Conditions are variables that influence the system's performance, and which may change over the lifetime of the system. Finally, resilient properties are variables modifying the relationship between performance and conditions. Figure 2 summarises the three variable types and the relationships between them in a conceptual model (hereafter termed the PCR Model).

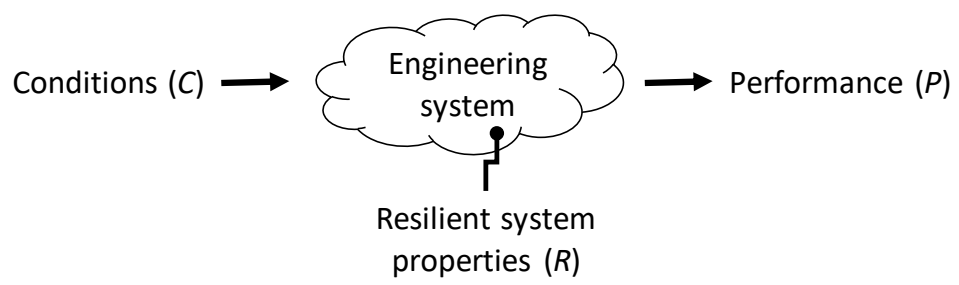

\section{Figure 2. The PCR Model: A model for understanding resilient systems (Wied et al., under review)}

Here, a system's performance $(\mathrm{P})$ is determined by the conditions $(\mathrm{C})$ under which it operates, and its resilient properties $(\mathrm{R})$. The three sets of variables and their relationships can be expressed as a function:

$$
P=f(C, R)
$$

In which,

- $\mathrm{P}$ is the set of value variables defining the performance of the system;

- $\mathrm{C}$ is the set of condition variables affecting $\mathrm{P}$;

- $\mathrm{R}$ is the set of mediating variables, which, together with $\mathrm{C}$, determine $\mathrm{P}$; and,

- $\mathrm{f}$ is the relationship between $\mathrm{P}, \mathrm{C}$, and $\mathrm{R}$.

Taking this view, the resilience of a system depends on the relationship between its performance and condition variables. The defining behavioural characteristic of a resilient system is its ability to modify this relationship, as illustrated in Figure 3.

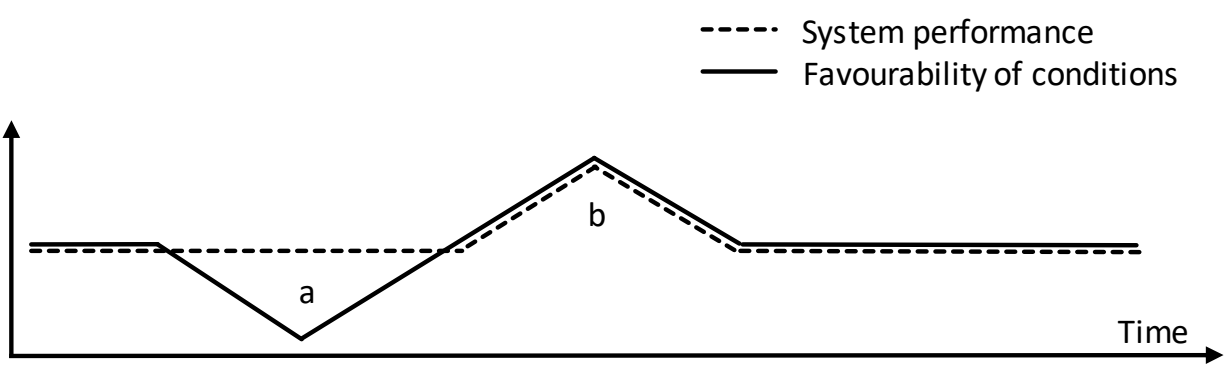

Figure 3. Resilient systems behaviour (Wied et al., under review)

As shown, a resilient system is able to sustain its level of performance under deteriorating conditions and improve its performance under favourable conditions. In doing so, a resilient system achieves an avoidance advantage and an exploitation advantage, denoted (a) and (b), respectively. The two types of advantage is sometimes called 'bounce back' and 'bounce forward', in the resilience literature (Meerow and Stults, 2016, p. 5). It follows, that the advantages granted by a system's resilient properties depends on the volatility of the conditions under which it operates, i.e. under certain and stable conditions, resilient system properties offer no performance advantage.

Armed with these concepts, we are now in a position to study resilient properties of a real-world system. 


\section{Resilient design properties in a driverless transport system}

In the following, the PCR Model is applied to identifying resilient properties in the design and development stage of a real-world system, seeking to answer the research question: How do resilient properties modify the relationship between performance and condition variables in the design and development phase of a driverless transport system?

\subsection{The case}

The selected case under study is titled 'Transforming Urban Planning Providing Autonomous Collective Mobility' (abbreviated TUPPAC). The project is a three-year development effort (November 1st, 2017 to October 31 st, 2020). The project aims to develop and demonstrate intelligent 'first and last mile' services, investigate user interaction and behaviour with driverless busses, and develop plans for integrating the system with a light rail transport system in Greater Copenhagen (to be completed: 2023-2024). The project is funded by Urban Innovative Actions (UIA), with a budget of DKK 31.4 million. The project is a collaboration between eight partners: Albertslund (municipality), Gladsaxe (municipality), Nobina a/s (commercial bus operator), IBM Denmark ApS (commercial technology supplier), Roskilde University (transport researchers), The Technical University of Denmark (DTU) (transport researchers), Gate 21, (a partnership between municipalities, research institutions and businesses in Greater Copenhagen), and Loop City (an association of ten urban municipalities) (TUPPAC, 2017).

\subsection{Methodology}

Following Yin (2014, p. 51), the present study is a single descriptive case study, employed to confirm, challenge and extend theory. This approach was chosen, first, because the model of resilient system properties, discussed in the previous section, is in the early stages of the research cycle (theory development), and neither the content of the categories, nor the relationships between them are clear in advance. Second, the aim of this study is to identify and classify variable types. Hence, there is no need to remove the system from its natural setting to control the attributes of those variables. Third, the case methodology lends itself well to the 'how' format of the research question, and the unit of analysis - the contemporary design and development phase of one system's life cycle (Yin, 2014, p. 9), specifically, the part that is within the scope of the TUPPAC project.

Choosing a case system in the design phase of its life cycle (De Weck et al., 2011, p. 36) minimises the scope for after-the-fact rationalisation. At the time of the case study, the eventual fate of the system remains unknown. Third, the system studied faces the problem of commitment under uncertainty, and there is a clear need to address the fundamental design problems involved. Fourth, in choosing a case illustrative of resilient system properties, the experience of the development team was likewise a factor. In particular, Nobina, IBM, Gate 21, and Loop City manage extensive portfolios of development projects, and are expected to bring a range of solutions to bear on the problems involved.

The system variables were identified and classified on the basis of the definitions of performance, conditions and resilient properties in the PCR Model. Variables were identified from two sources: 1) The project description, as detailed in the application for funding for UIA (TUPPAC, 2017) (submitted April 14th, 2017), and 2) interviews with representatives of each of the eight project partner organisations mentioned above (through November 2017). The separation in time between the two sources represents the time from submission of the project application until notification of funding (November 1st. 2017). Representatives with the closest involvement in the project from all involved project partners were selected as interviewees. Interviews were conducted from November 17th to 30th. The semi-structured interviews followed (Kvale, 1996, p. 145), and were conducted on the basis of shared interview guide, moving from open questions about the assumptions underpinning the project (introducing questions), followed by probing, follow-up, interpreting, and specifying questions, before concluding with structuring questions. To encourage openness, interviewees were guaranteed anonymity, and that no direct quotes would be published. Interviews were conducted in-person or over the phone/Skype. The interview duration was about one hour. Interviews were recorded and transcribed. Transcriptions were subsequently coded by variable type, and statements were triangulated for consistency and accuracy against the project description and against the responses given by other interviewees. 


\subsection{Results}

Table 1 gives an overview of the identified performance and condition variables, and the resilient properties. As described in Section 3, performance variables are any value variable defining the performance of a system. Conditions are defined as variables that affect the system's performance, and which may change over the lifetime of the system. Finally, resilient properties are defined as variables modifying the relationship between performance and conditions. The categorisation of performance variables in the first column follows the structure of the implementation work packages of the project. Anonymised references to interviewees are noted in parenthesis. Resilient properties are numbered for subsequent reference.

\section{Table 1. Performance, conditions and resilient properties}

\begin{tabular}{|c|c|c|}
\hline Performance & Conditions & Resilient properties \\
\hline $\begin{array}{l}\text { Obtain legislative approval: } \\
\text { As its first objective, the } \\
\text { project must obtain } \\
\text { legislative approval from } \\
\text { The Danish Transport } \\
\text { Authorities for activities } \\
\text { involving testing driverless } \\
\text { technology on public roads } \\
\text { (TUPPAC, 2017, p. 64). The } \\
\text { format of the application and } \\
\text { the requirements developed } \\
\text { through the application } \\
\text { process are themselves } \\
\text { deliverables of the project, } \\
\text { setting precedence for } \\
\text { further development of the } \\
\text { system (h). }\end{array}$ & $\begin{array}{l}\text { Will the system be } \\
\text { approved? Legislative } \\
\text { approval is not guaranteed, } \\
\text { and will be conditioned by } \\
\text { safety requirements, with } \\
\text { which the system must } \\
\text { comply. These } \\
\text { requirements will not be } \\
\text { fully known before the end } \\
\text { of the approval process (h, } \\
\text { f). Testing autonomous on- } \\
\text { demand service outside } \\
\text { predetermined routes, is an } \\
\text { especially controversial } \\
\text { activity, which could be } \\
\text { limited by legal safety } \\
\text { requirements (h). }\end{array}$ & $\begin{array}{l}\text { 1) Postponement: At the time of applying for UIA- } \\
\text { funding, the legislative framework for testing } \\
\text { driverless vehicles on public roads was still underway } \\
\text { through Parliament. Project launch was scheduled } \\
\text { after legislation was expected to be passed. Should the } \\
\text { legislative process have been delayed, the project was } \\
\text { prepared for further postponement (TUPPAC, 2017, } \\
\text { p. 64) (h). Should the legislation have been rejected } \\
\text { by Parliament or proved prohibitively restrictive, the } \\
\text { project could have been aborted before major costs } \\
\text { were sunk (TUPPAC, 2017, p. 64). } \\
\text { 2) Modifiability: During project design, meetings } \\
\text { were held with transport authorities to obtain early } \\
\text { indications about the likely legal requirements, then } \\
\text { underway. These meetings were used to avoid } \\
\text { legislative show-stoppers in the project specifications. } \\
\text { Other activities were kept deliberately vague to allow } \\
\text { for later modification (h, e). Legislation was passed } \\
\text { July 1st, and project activities can now be designed } \\
\text { with a high probability of approval (h). Rather than } \\
\text { seeking legislative approval for all project activities in } \\
\text { a single application, the application process is divided } \\
\text { into parallel applications. This is done to make } \\
\text { approval of the less controversial activities } \\
\text { independent of the more controversial ones, both in } \\
\text { terms of time-to-approval, risk of rejection, and added } \\
\text { requirements (h). }\end{array}$ \\
\hline $\begin{array}{l}\text { Demonstrate operational } \\
\text { safety: The number of } \\
\text { accidents is to reduce to zero } \\
\text { during the project period } \\
\text { (TUPPAC, 2017, p. } 21 \text { ). In } \\
\text { addition, the project is to } \\
\text { produce safety guidelines for } \\
\text { subsequent developments } \\
\text { (TUPPAC, 2017, p. } 30 \text { ). A } \\
\text { severe accident involving } \\
\text { fatalities could cause } \\
\text { authorities to call a halt to } \\
\text { public road testing, pending } \\
\text { a review (e). This risk is } \\
\text { compounded by parallel } \\
\text { development projects, any of } \\
\text { which could be the cause (f). }\end{array}$ & $\begin{array}{l}\text { Will it be safe? The } \\
\text { operational safety of the } \\
\text { system depends on a range } \\
\text { of issues. These include, } \\
\text { issues with the system } \\
\text { itself, interactions with } \\
\text { other road users, as well as } \\
\text { deliberate disruption, } \\
\text { sabotage, hacking, } \\
\text { hijacking, etc. (f, e, a, h). }\end{array}$ & $\begin{array}{l}\text { 3) Postponement: On the basis of experiments } \\
\text { abroad, this project was launched at a time when the } \\
\text { core technology was judged sufficiently mature to } \\
\text { achieve an acceptable safety record (h, f, d). } \\
\text { 4) Control: The system will be developed through a } \\
\text { series of increasingly complex, controlled } \\
\text { environments, from pre-tests in enclosed areas, over } \\
\text { user tests in simple environments, to full operational } \\
\text { service in open complex environments. Only when } \\
\text { operational safety and reliability has been } \\
\text { demonstrated on in one best bed will the system } \\
\text { advance to the next one (TUPPAC, } 2017 \text {, pp. } 22,40 \text { ). } \\
\text { 5) Trial and error: On both the hardware and the } \\
\text { software side, the project allows for a number of trial- } \\
\text { and-error cycles through which the system is } \\
\text { incrementally modified and improved (TUPPAC, }\end{array}$ \\
\hline
\end{tabular}




\begin{tabular}{|c|c|c|}
\hline & & $\begin{array}{l}\text { 2017, p. 37). On the software side, 'white hat' hackers } \\
\text { will attempt to identify IT-security weaknesses } \\
\text { (TUPPAC, 2017, p. 39). }\end{array}$ \\
\hline $\begin{array}{l}\text { Demonstrate practical } \\
\text { applicability: The project is } \\
\text { to develop, test, and } \\
\text { demonstrate practical } \\
\text { solutions to the principal } \\
\text { problems of integrating } \\
\text { driverless bus transport into } \\
\text { the public mobility chain } \\
\text { (TUPPAC, 2017, p. 20). } \\
\text { According to project } \\
\text { partners, this objective } \\
\text { entails a number of } \\
\text { developmental objectives, } \\
\text { including demonstrating } \\
\text { flexible routing (h, f), virtual } \\
\text { stops/on-demand service (h, } \\
\text { f, a), increasing the speed of } \\
\text { the vehicles to normal traffic } \\
\text { speeds (f, a, e), } \\
\text { demonstrating integration } \\
\text { with other modes of } \\
\text { transport in the public } \\
\text { mobility chain (TUPPAC, } \\
\text { 2017, p. 50), (f, g), and } \\
\text { demonstrate integration with } \\
\text { other road users (TUPPAC, } \\
\text { 2017, p. 37), (f, e). }\end{array}$ & $\begin{array}{l}\text { Will the system prove } \\
\text { practical? Demonstrating } \\
\text { the practical applicability } \\
\text { of the system hinges on } \\
\text { whether the system can } \\
\text { operate under the full } \\
\text { range of seasonal weather } \\
\text { conditions (f), whether } \\
\text { safety standards are } \\
\text { compatible with normal } \\
\text { traffic speeds (f, a, e), how } \\
\text { well the system } \\
\text { synchronises with the } \\
\text { public mobility chain, (f, } \\
\text { e), if the time-loss involved } \\
\text { in on demand service is } \\
\text { acceptable (f), and the } \\
\text { behaviour of other road } \\
\text { users (f, e). }\end{array}$ & $\begin{array}{l}\text { 6) Redundancy: For all initial tests, a human steward } \\
\text { will be on-board, or have the option of remotely } \\
\text { taking control of the vehicles (TUPPAC, 2017, p. 37). } \\
\text { Even if the technology proves unable to handle some } \\
\text { complex situations initially, the human steward can } \\
\text { bridge the gap. This allows user data on e.g. on- } \\
\text { demand service to be gathered before the system is } \\
\text { fully developed (f, a). Eventually eliminating need for } \\
\text { an on-board steward is necessary for realising the } \\
\text { economic advantages of the technology. The cost of } \\
\text { the driver is estimated at two thirds of the operational } \\
\text { cost of traditional bus transport (f). } \\
\text { 7) Influence: The results of the system tests (if } \\
\text { successful) will influence the design of the LRT } \\
\text { stations (a, e), ensuring access and guidance } \\
\text { infrastructure. In addition, as part of the project, bus } \\
\text { lanes will be fitted with guidance equipment and signs } \\
\text { for other road users, reducing the complexity of the } \\
\text { environment (e, f). } \\
\text { 8) Flexible goals: The project is to "develop, test and } \\
\text { demonstrate practical solutions to the principal } \\
\text { problems of integrated, driverless bus transport" } \\
\text { (TUPPAC, 2017, p. 20),. There are many ways to } \\
\text { achieve that goal (f), and some deliverables of the } \\
\text { project are kept deliberately vague, hedging against } \\
\text { uncertainties in the system's capabilities and } \\
\text { requirements (a, f, h). Experience, requirements, and } \\
\text { data guiding subsequent developments are project } \\
\text { outputs in themselves (TUPPAC, 2017, p. 18). This } \\
\text { project thus influences the scope and the direction of } \\
\text { subsequent development efforts in the field (e, f). } \\
\text { 9) Multi-functionality: Driverless technology has } \\
\text { broader applications than the 'first and last mile } \\
\text { problem' (f). Therefore, given positive results, the } \\
\text { success of the system is only partially dependent on } \\
\text { solving this problem (and by extension the parallel } \\
\text { development of the LRT system). The option of } \\
\text { alternative applications, e.g. as stand-alone system, is, } \\
\text { at least in principle, retained (e, h). }\end{array}$ \\
\hline $\begin{array}{l}\text { Demonstrate positive user } \\
\text { response: The project is to } \\
\text { investigate and solve the } \\
\text { principal problems of user } \\
\text { interaction with the system } \\
\text { (TUPPAC, 2017, p. 43). } \\
\text { This entails several } \\
\text { achievements, including ease } \\
\text { and comfort of use, ease of } \\
\text { transfer to other traffic } \\
\text { nodes, affordability, and at } \\
\text { least partial superiority over } \\
\text { competing alternatives (f, e, } \\
\text { a, g). The system is to be a }\end{array}$ & $\begin{array}{l}\text { How will users respond to } \\
\text { the system? The user } \\
\text { response to the system } \\
\text { depends on a number of } \\
\text { factors, including whether } \\
\text { users like the service (a, f), } \\
\text { whether enough users will } \\
\text { demand it (e), whether } \\
\text { users will accept } \\
\text { transitions between modes } \\
\text { of transport (f), as well as } \\
\text { the attractiveness of } \\
\text { competing substitutes (f). }\end{array}$ & $\begin{array}{l}\text { 10) Pre-emption: Because of the possibilities for } \\
\text { reducing the complexity of the operation, through } \\
\text { special lanes and dedicated guidance infrastructure, } \\
\text { the advent of driverless public bus transport is } \\
\text { expected to be ahead of autonomous cars in complex } \\
\text { urban areas (TUPPAC, } 2017, \text { p. } 18 \text { ), perhaps by as } \\
\text { much as a decade (f). This allows the project to pre- } \\
\text { empt what may prove to be a significant competing } \\
\text { substitute (f, g). } \\
\text { 11) Influence: The project is able to selectively } \\
\text { recruit early users. Early users include students at the } \\
\text { Technical University of Denmark, whom are expected } \\
\text { to be both physically fit and curious (e). Later users }\end{array}$ \\
\hline
\end{tabular}




\begin{tabular}{|c|c|c|}
\hline $\begin{array}{l}\text { practical improvement of } \\
\text { users' everyday life, beyond } \\
\text { the expected initial } \\
\text { excitement by the novelty of } \\
\text { the technology }(a, b, g) \text {. }\end{array}$ & & $\begin{array}{l}\text { will be commuters to an industrial area with a high } \\
\text { expected demand (a). In addition, the project includes } \\
\text { an awareness campaign aimed at shaping the attitudes } \\
\text { of potential users of the system (TUPPAC, 2017, p. } \\
\text { 20). } \\
\text { 12) Modifiability: Through the project, the system is } \\
\text { to be developed and modified to meet user } \\
\text { requirements, and off-set perceived disadvantages of } \\
\text { the technology. These include lower cost, more } \\
\text { frequent service, and the possibility of on-demand and } \\
\text { flexible routing (f). } \\
\text { 13) Flexible goals: It is not a requirement that the } \\
\text { technology appeals to all user groups, only that the } \\
\text { project identifies the relevant users (e, a). }\end{array}$ \\
\hline $\begin{array}{l}\text { Insure further development: } \\
\text { The project is to be part of a } \\
\text { development chain, bridging } \\
\text { the final technology } \\
\text { readiness levels, and the } \\
\text { resulting technology is to be } \\
\text { scalable and transferable } \\
\text { (TUPPAC, 2017, p. 18). } \\
\text { This entails making the } \\
\text { technology ready for } \\
\text { commercial use (f). In } \\
\text { addition, the project is to } \\
\text { attract funding for parallel } \\
\text { and subsequent projects for } \\
\text { the next phases of } \\
\text { development (e, a, e, c), and } \\
\text { ensuring political backing } \\
\text { for subsequent efforts (a, e). }\end{array}$ & $\begin{array}{l}\text { Will development } \\
\text { continue? Further } \\
\text { development of the system } \\
\text { efforts depends on positive } \\
\text { results of this project }(\mathrm{f}, \mathrm{c}) \text {, } \\
\text { on continued political } \\
\text { backing, and on obtaining } \\
\text { funding for further } \\
\text { developments }(\mathrm{a}, \mathrm{e}, \mathrm{g}) \text {. }\end{array}$ & $\begin{array}{l}\text { 14) Influence: Project partners are already involved } \\
\text { in parallel development projects in the area, and } \\
\text { expect to use the results of this project to leverage } \\
\text { funding for subsequent development efforts, directed } \\
\text { at system problems identified, but not solved, in this } \\
\text { project (c, f, a, g). } \\
\text { 15) Influence: As a channel of influence, several } \\
\text { project partners report directly to political decision- } \\
\text { makers (TUPPAC, } 2017, \text { p. } 19) \text {. This allows the } \\
\text { project to increase political awareness and to shape } \\
\text { political attitudes to the system (a, e, g). }\end{array}$ \\
\hline
\end{tabular}

\section{Discussion}

As described, in the case study conducted herein, designers face the problem of commitment under uncertainty. The performance of the system they are building is influenced by a large number of conditions, many of which are both unknown and beyond their direct control. Designers are nonetheless forced to make irreversible design commitments. As shown, attempting to circumvent this problem, designers resort to a range of resilient design properties, seeking to modify the relationship between performance and conditions. The resilient properties identified can be classified into six categories, as illustrated in Figure 4:

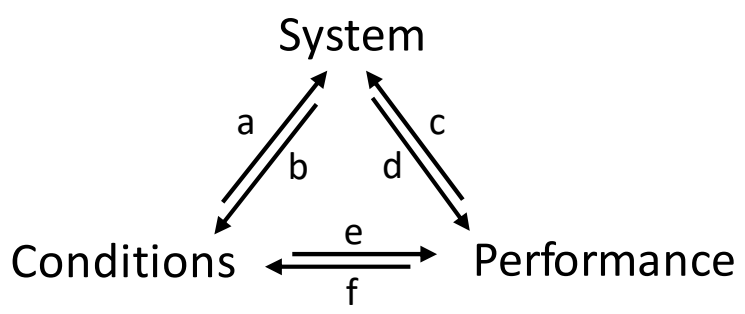

Figure 4. A classification scheme for resilient properties

This classification is derived by asking: What is adapting to what? As shown, this yields six classes of resilient properties. Thus, a) contains resilient properties that fit conditions to a given system. Following this scheme, Table 2 classifies the resilient properties identified in Table 1. 
Table 2. Classification of resilient properties

\begin{tabular}{|l|l|}
\hline Classification of resilient properties & Identified resilient properties \\
\hline $\begin{array}{l}\text { a) Fit conditions to the system: These } \\
\text { properties modify conditions to fit a } \\
\text { given system. }\end{array}$ & $\begin{array}{l}\text { 1) Postponement to fit legislation to the system } \\
\text { 4) Control to fit test conditions to the system } \\
\text { 7) Influence to fit operating conditions to the system } \\
\text { 10) Pre-emption to fit the competitive situation to the system } \\
\text { 14) Influence to fit further developments to the system } \\
\text { 15) Influence to fit political attitudes to the system }\end{array}$ \\
\hline $\begin{array}{l}\text { b) Fit the system to conditions: These } \\
\text { properties modify a system to fit given } \\
\text { conditions. }\end{array}$ & 2) Modifiability to fit the system to legislative conditions \\
\hline $\begin{array}{l}\text { c) Fit performance to the system: } \text { These } \\
\text { properties modify performance } \\
\text { requirements to fit a given system. }\end{array}$ & 8) Flexible goals to fit performance standards to the system \\
\hline $\begin{array}{l}\text { d) Fit the system to performance: These } \\
\text { properties modify a system to fit given } \\
\text { performance requirements. }\end{array}$ & $\begin{array}{l}\text { 5) Trial and error to fit the system to safety requirements } \\
\text { 6) Redundancy to fit early performance to requirements } \\
\text { 12) Modifiability to fit performance to user preferences }\end{array}$ \\
\hline $\begin{array}{l}\text { e) Fit conditions to performance: } \text { These } \\
\text { properties modify conditions to fit given } \\
\text { performance requirements. }\end{array}$ & $\begin{array}{l}\text { 3) Postponement to fit the technology to safety requirements } \\
\text { 11) Influence to fit early users to the system's performance }\end{array}$ \\
\hline $\begin{array}{l}\text { f) Fit performance to conditions: } \text { These } \\
\text { properties modify performance } \\
\text { requirements to fit given conditions. }\end{array}$ & $\begin{array}{l}\text { 9) Multi-functionality to fit performance to alt. applications } \\
\text { 13) Flexible goals to fit users to the system's performance }\end{array}$ \\
\hline
\end{tabular}

As shown, the resilient properties cluster around fitting conditions to the system. At this stage, designers are 'setting the scene' for their creation, and are working to set up the legislative, physical, competitive, and political conditions in which their system is to operate. To this end, resilient properties exploiting timing to fit conditions to the system predominate. Postponement is used to ensure sufficient technological maturity. Conversely, pre-emption is employed to get ahead of potential competitors. Properties seeking to internalise conditions into the system are also employed to fit conditions to the system. Through control measures, conditions are modified, or the odds of fit are stacked in the system's favour by influencing conditions.

As shown in Table 1, resilient properties are identified right along the task sequence of the project, from legal approval to hand-over to the next stage of the system's life cycle. Along this sequence, the performance of the later tasks are themselves conditioned by the preceding ones. It is also observed, that, while some resilient properties address specific conditions, e.g. legislative approval, others are generic, addressing whole clusters of conditions at once, e.g. trial and error. As an additional observation, some resilient design properties seems to form a 'ladder of escalation', ensuring that if one resilient property proves insufficient to modify the relationship between performance and conditions, another resilient property can take over. As an example, in demonstrating the practical applicability of the system, resilient properties 6 through 9 form escalating attempts to modify the relationship between this performance variable and the conditions upon which it depends.

Finally, the resilient properties identified here are merely those currently under consideration by the system's designers. This is not an exhaustive list, and it is not clear that the properties identified are the most relevant ones. These may be fertile questions for further research.

\section{Conclusions}

Using the conceptual model of resilient systems as a framework, a number of performance and condition variables were identified, along with the resilient properties modifying the relationship between them. On this basis, it is possible to answer the research question: How do resilient properties modify the relationship between the performance and condition variables in the design of an early-stage driverless transport system? 
The resilient properties of the system modify the relationship between performance and conditions in six distinct ways. Resilient properties seek to attain a three-way 'fit' between a system, its performance, and the conditions under which it operates. By doing so, resilient properties allow circumvention of the problem of commitment under uncertainty. Resilient properties have both offensive and defensive aspects, allowing the system to 'bounce back' under adverse conditions and to 'bounce forward' under favourable conditions.

Theoretically, the approach to resilient systems taken here cuts across many aspects of systems design, touching upon robust decision making, muddling through, operations research, risk management, and other schools of thought. Practically, this study takes steps to making resilient systems thinking a practical field, applicable to the problems faced by designers of real-world systems.

\section{Acknowledgements}

The authors would like to thank the representatives of the following organisations for freely giving their time to this study: Gladsaxe Municipality, Nobina Denmark, IBM Denmark ApS, The Technical University of Denmark, Roskilde University, Loop City, Albertslund Municipality, and Gate 21. In addition, the authors gratefully acknowledges the Brightline Initiative and the DTU-NTNU Alliance PhD Programme for funding this study.

\section{References}

Aaltonen, K., Ahola, T. and Artto, K. (2017), "Something old, something new: Path dependence and path creation during the early stage of a project", International Journal of Project Management, Vol. 35 No. 5, pp. 749-762. https://doi.org/10.1016/j.ijproman.2017.03.004

Antunes, R. and Gonzalez, V. (2015), "A Production Model for Construction: A Theoretical Framework", Buildings, Vol. 5 No. 1, pp. 209-228. https://doi.org/10.3390/buildings5010209

Arrow, K.J. (1955), Economic Aspects of Military Research and Development, RAND Cooperation Document D3142.

Carpenter, S., Walker, B., Anderies, M, and Abel, N. (2001), "From Metaphor to Measurement: Resilience of What to What?", Ecosystems, Vol. 4 No. 8, pp. 765-781. https://doi.org/10.1007/s10021-001-0045-9

Chaudhuri, D.J. and Chaudhuri, A. (2011), "AGILE Burndown Chart deviation - Predictive Analysis to Improve Iterative Planning”, International Conference on Software Engineering Research and Practice, pp. 443-449.

De Weck, O., Magee, C.L. and Roos, D. (2011), Engineering Systems: Meeting Human Needs in a Complex Technological World, The MIT Press, Cambridge, Massachusetts.

Holling, C.S. (1973), "Resilience and stability of ecological systems", Annual Review of Ecology and Systematics, Vol. 4, pp. 1-23. https://doi.org/10.1146/annurev.es.04.110173.000245

Hosseini, S., Barker, K. and Ramirez-Marquez, J.E. (2016), “A review of definitions and measures of system resilience", Reliability Engineering and System Safety, Vol. 145, pp. 47-61. https://doi.org/10.1016/j.ress.2015.08.006

Hubbard, D.W. (2009), The Failure of Risk Management: Why It's Broken and How to Fix It, John Wiley \& Sons.

Kvale, S. (1996), Interviews: an introduction to qualitative research interviewing, Sage Publications. https://doi.org/10.1016/S1098-2140(99)80208-2

Lempert, R.J., Popper, S.W. and Bankes, S.C. (2003), "Shaping the Next One Hundred Years: New Methods for Quantitative, Long-Term Policy Analysis", Technological Forecasting and Social Change, RAND, Vol. 71 No. 3, pp. 305-307. https://doi.org/10.1016/j.techfore.2003.09.006

Martin-Breen, P. and Anderies, J.M. (2011), Resilience: A Literature Review. [online] The Bellagio Initiative. Available at: https:/opendocs.ids.ac.uk/opendocs/handle/123456789/3692

Maylor, H. (2010), Project Management, 4th ed., Financial Times, Prentice Hall.

Meerow, S. and Stults, M. (2016), "Comparing conceptualizations of urban climate resilience in theory and practice”, Sustainability, Vol. 8 No. 7, pp. 1-16. https://doi.org/10.3390/su8070701

Merrow, E.W., Phillips, K.E. and Myers, C.W. (1981), Understanding Cost Growth and Performance Shortfalls in Pioneer Process Plants, RAND Corporation, Santa Monica, USA.

Mitchell, P.J. (1985), "Holding down the cost of change”, In: Del Re, R. and McKittrick, H.V. (Eds.), The Role of the Resident Engineer, American Society of Civil Engineers, pp. 128-137.

Rittel, H.W.J. and Webber, M.M. (1973), "Dilemmas in a General Theory of Planning”, Policy Sciences, Vol. 4 No. 2, pp. 155-169. https://doi.org/10.1007/BF01405730

Rose, A. (2017), Defining and Measuring Economic Resilience from a Societal, Environmental and Security Perspective, Springer, pp. 19-27. https://doi.org/10.1007/978-981-10-1533-5

Schelling, T.C. (1980), The Strategy of Conflict, Reprint, Harvard University Press. 
Sebastian, S.T. (2017), “Agile development and the constraints of physicality: A network theory-based causeandeffect analysis", Proceedings of the International Conference on Engineering Design (ICED 17).

Simon, H.A. (1997), "The sciences of the artificial, (third edition): By Herbert A. Simon. MIT Press, Cambridge, MA. (1996). 231 pages. \$14.50”, Computers \& Mathematics with Applications, Vol. 33 No. 5, p. 130. https://doi.org/10.1016/S0898-1221(97)82941-0

TUPPAC (2017), “Application for Urban Innovative Actions”, submitted April 2017, confidential, unpublished.

Veenvliet, K.T., Broenink, J.F. and Bonnema, G.M. (2011), Systems Design and Engineering: Facilitating Multidisciplinary Development Projects, CRC Press.

von Neumann, J. and Morgenstern, O. (1944), Theory of Games and Economic Behavior, Princeton University Press. https://doi.org/10.1515/9781400829460

Woods, D. (2006), "Engineering Organizational Resilience to Enhance Safety: A Progress Report on the Emerging Field of Resilience Engineering", Proceedings of the Human Factors and Ergonomics Society Annual Meeting, pp. 2237-2241. https://doi.org/10.1177/154193120605001910

Yin, R.K. (2014), Case Study Research Design and Methods, 5th ed., Sage, Thousand Oaks, CA. https://doi.org/10.3138/cjpe.30.1.108

Morten Wied, PhD Fellow

Technical University of Denmark, Management Engineering

Building 424, Room 022, 2800 Kongens Lyngby, Denmark

Email: mowi@dtu.dk 